JBEE : JOURNAL BUSINESS, ECONOMIC AND ENTREPRENEURSHIP

https://journal.shantibhuana.ac.id/index.php/bee/index

JBEE Volume 3 No 12021

\title{
ANALISIS PENGARUH STRATEGI PEMASARAN TERHADAP PENJUALAN ANYAMAN BIDAI KERAJINAN TANGAN MASYARAKAT DESA JAGOI KECAMATAN JAGOI BABANG KABUPATEN BENGKAYANG
}

\author{
Yuliana
}

Akademi Keuangan Dan Perbankan Graha Arta Khatulistiwa Pontianak yuliana8284@gmail.com

Received: 12 Maret 2021; Accepted: 18 Maret 2021; Published: 01 Mei 2021

\begin{abstract}
Abstrak
Penelitian ini terlaksana melalui proses wawancara dengan pemilik usaha kerajinan anyaman bidai di desa Jagoi Kecamatan Jagoi Babang, Kabupaten Bengkayang, karena produk kerajinan tangan anyaman bidai ini memiliki kualitas yang baik sehingga menarik untuk dikaji dan merupakan salah satu ciri khas produk kerajinan di Kabupaten Bengkayang. Tujuan dari penelitian ini adalah (1) Untuk mengetahui pengaruh strategi pemasaran terhadap penjualan anyaman bidai Desa Jagoi Kecamatan Jagoi Babang Kabupaten Bengkayang, (2) Untuk mengetahui apa saja kendala penjualan yang dihadapi oleh pengrajin Anyaman Bidai Desa Jagoi Kecamatan Jagoi Babang Kabupaten Bengkayang. Subjek penelitian yang diambil yaitu tempat usaha kerajinan anyaman bidai di desa Jagoi. Metode pengumpulan data yang digunakan adalah metode dokumentasi, metode kuesioner, dan metode wawancara. Hasil penelitian menunjukkan bahwa F hitung sebesar 1.822 dengan signifikansi sebesar 0,018 karena signifikansi < alpha (0.05) maka HO ditolak: artinya terdapat pengaruh yang signifikan antara strategi pemasaran terhadap penjualan anyaman bidai. Strategi pemasaran berpengaruh sangat kuat dan dominan terhadap penjualan dengan angka sebesar 3.466 dengan signifikansi sebesar 0.018, artinya bahwa ada pengaruh secara signifikan antara strategi pemasaran dengan penjualan. Karena koefisien korelasi nilainya positif, maka berarti strategi pemasaran berpengaruh positif dan signifikan terhadap penjualan. Jadi dalam kasus ini dapat disimpulkan bahwa strategi pemasaran berpengaruh positif terhadap penjualan hasil kerajinan anyaman bidai.
\end{abstract}

Keywords: Strategi Pemasaran (undifferentiated marketing, differentiated marketing,concentrated marketing) dan Penjualan 


\section{PENDAHULUAN}

\section{Latar Belakang}

Kerajinan anyaman adalah salah satu dari sekian jenis kerajinan yang terbesar diseluruh pelosok tanah air. Kerajinan tangan sebagai usaha untuk kelangsungan hidup bagi masyarakat pedesaan, karena hingga kini masih didapat jenis kerajinan anyaman yang bermacam-macam sesuai dengan kreativitas masyarakat setempat, salah satunya adalah kerajinan anyaman tikar bidai yang ada di Desa Jagoi Kecamatan Jagoi Babang Kabupaten Bengkayang. Home Industry ini tumbuh dan berkembang di pedesaan, dengan kreativitas dan keterampilan masyarakat dalam pengelolaan rotan dan kulit kayu menjadi suatu karya yang bernilai tinggi.

Di lain pihak dengan munculnya produk sejenis dipasaran menyebabkan persaingan semakin ketat antara produsen yang memasarkan produk sejenis. Menghadapi persaingan ketat antar produsen harus dapat menentukan langkah terbaik dalam mempertahankan keberadaan produk tersebut dipasar dan mengusahakan produk yang dijual tetap disenangi konsumen. Dengan demikian produk kerajinan tangan anyaman bidai ini memiliki kualitas yang baik sehingga menarik untuk dikaji dan bisa mengangkat nama Kecamatan Jagoi khususunya Desa Jagoi, sebagai penghasil kerajinan anyaman bidai terbaik di Kalimantan Barat.

\section{Kajian Teori}

Anyaman Bidai

Tikar Bidai adalah produk asli khas hasil para pengrajin masyarakat Desa Jagoi yang turuntemurun dari nenek moyang, dari jaman ke jaman hingga sampai saat ini. Bidai atau kasah adalah sebutan bidai dalam bahasa daerah Desa Jagoi. Bidai merupakan kerajinan tangan yang terbuat dari rotan dan kulit kayu. Bidai adalah tikar yang terbuat dari bilah-bilah rotan dan kulit kayu. Bidai ini merupakan tikar tradisional asli produk dari Kalimantan, tikar bidai ini akan memberikan suasana yang sejuk jika ditempatkan diruang tamu, dan sangat cocok digunakan di daerah yang beriklim panas seperti Indonesia. Tikar bidai ini dapat digunakan layaknya seperti karpet di ruang tamu, ruang tidur, ruang makan, ruang keluarga dan lain-lain. Selain itu, Bidai juga dijual untuk kebutuhan keluarga. Untuk pemasarannya bidai ini dijual ke negara tetangga, Serikin (Sarawak, Malaysia), hingga saat ini.

Karena sifatnya yang sedikit menyimpan debu dan sangat mudah dibersihkan, bidai sangat cocok digunakan untuk berbagai macam keperluan. Tikar bidai ini sangat kuat (tahan lama) dan ini merupakan salah satu keunggulan dari kerajinan tikar bidai. Apabila terkena kotoran seperti noda, tikar ini sangat mudah dibersihkan dengan dilap menggunakan kain basah maupun langsung dijemur. Sekarang bahan bakunya sudah langka dan sulit untuk didapatkan. Bahkan untuk mendapatkan bahan bakunya pun pengusaha pengrajin membelinya dengan cara memesan bahan baku dari Kalimantan Tengah dan Kalimantan Selatan. Desa Jagoi, Kecamatan Jagoi Babang, Provinsi Kalimantan Barat, kaya akan potensi, salah satu diantaranya anyaman tikar, yakni bidai. Selama ini banyak yang belum tahu bahwa bidai adalah hasil produk masyarakat perbatasan di Desa Jagoi.

\section{Alat Yang Digunakan Untuk Membuat Bidai}

Ibu Roslinda menerangkan lebih jauh, dalam proses atau pembuatan tikar bidai ini, ada beberapa alat yang digunakan yakni sebagai berikut: kayu penjepit, kayu penahan, palu, sengkalan, pisau kecil, parang, kayu pengukur, paku, kayu kecil, parang dari kayu dan meteran.

1. Kayu Penjepit. Kayu penjepit ini berfungsi untuk menjepit kulit kayu tarap/pantongan pada proses pembuatan tikar bidai tahap awal. Pada bagian ujung kayu terdapat anyaman rotan yang berfungsi untuk merapatkan kayu.

2. Kayu Penahan. Kayu penahan berfungsi untuk menahan bagian ujung kulit kayu pantongan yang sudah dibentangkan supaya tidak bergeser, agar waktu penganyamannya mudah.

3. Palu. Palu berfungsi untuk memukul kulit kayu tarap/pantongan yang baru diambil dari hutan sampai pipih, rapi supaya mudah dibentuk. 
4. Sengkalan. Sengkalan berfungsi sebagai alas untuk memukul kulit kayu tarap/pantongan supaya rapi.

5. Pisau Kecil. Pisau Kecil digunakan untuk meraut rotan supaya halus dan digunakan juga untuk memotong bagian ujung kulit kayu tarap yang melebihi ukuran yang dipergunakan.

6. Parang. Parang adalah benda yang terbuat dari besi, yang bisa digunakan masyarakat, atau para petani dan pekebun biasanya untuk menebang pohon. Parang digunakan untuk memotong dan mengambil rotan dan kayu tarap/pantongan di hutan.

7. Kayu Pengukur (mal). Kayu Pengukur (mal) adalah alat yang berfungsi untuk mengukur kulit kayu- tarap/pantongan yang akan dijadikan tikar bidai.

8. Paku. Paku adalah benda yang terbuat dari tembaga, yang berbentuk runcing pada bagian ujungnya. Paku berfungsi untuk memberi lubang pada bagian anyaman tikar, paku digunakan pada proses finishing tikar bidai.

9. Kayu Penusuk. Kayu penusuk merupakan alat yang digunakan dalam membuat tikar bidai yang berfungsi untuk memasukan ujung kulit kayu tarap atau mendorong lurus kulit kayu supaya kulit kayu tersebut masuk dalam galah-galah anyaman dan dilakukan pada saat proses ngalape supaya anyaman tidak mudah lepas dan bidai terlihat rapi.

10. Parang dan Kayu. Parang dari kayu adalah salah satu alat untuk membuat kerajinan tikar bidai. Parang kayu ini berfungsi sebagai alat untuk merapatkan bagian kulit kayu pada proses menganyam.

11. Meteran. Meteran adalah alat untuk mengukur panjang dan lebarnya suatu benda. Meteran berfungsi untuk mengukur rotan, dan kulit kayu yang akan dijadikan tikar bidai.

\section{Bahan Baku Pembuatan Bidai}

Tanaman rotan dan kulit kayu pada umumnya tumbuh tanpa ditanam dan tidak memerlukan pemeliharaan. Rotan yang nama latinnya
"Calamus sp", itu termasuk bangsa palmae. Tumbuhan rotan ini banyak terdapat di hutanhutan diseluruh Indonesia, terutama di Sumatera, Kalimantan, dan Sulawesi. Rotan adalah jenis tanaman palm yang merambat yang dapat tumbuh sampai panjang 100 meter lebih. Kulit rotan bagian luar dikerat dan menghasilkan rotan kulitan yang disebut tali anyam kulitan, batang rotan beruas banyak, kulitnya licin, berkilap, sifat rotan ialah pegas, elastis, dan kuat.

Rotan merupakan tanaman tropis, yang tumbuh di tanah-tanah rendah dan daerah pegunungan. Tanaman ini memiliki batang panjang dan lentik, merambat sampai berpuluh-puluh meter pada batang pohon yang lain. Semasa mudanya pohon rotan berupa rumpun, yang serupa dengan pohon salak, dengan bertambahnya umur, batang akan memanjang, menjalar pada pohon di sekitarnya sebagai panjatan.

Biasanya rotan tumbuh secara liar didalam hutan yang sulit dijangkau orang, oleh karena itu bagi pemungut untuk mencapai lokasi tanaman rotan kadang-kadang memerlukan waktu berhari-hari. Lokasi yang sulit dicapai. Tanaman rotan tumbuh secara alami dan liar, maka para pemungut sulit untuk memilih lokasi yang ditumbuhi suatu jenis rotan tertentu yang dikehendaki, oleh karena itu orang mulai memikirkan dan mencoba untuk menanam rotan di pekarangan rumah. Tanaman rotan termasuk dalam familia palmae dengan ciri khusus yaitu dengan adanya alat pemanjat yang disebut ciri atau flagella.

Beberapa jenis rotan yang sering dipergunakan sebagai bahan baku anyaman, antara lain:

1. Rotan Saga

Pada umumnya tumbuh di dataran rendah sampai pada ketinggian 200 meter di atas permukaan laut. Rotan saga ini tumbuhnya berumpun dan memanjat pada pohon yang ada disekitarnya dengan ketinggian mencapai 30 meter. Batang rotan ini mempunyai lapisan silica yang tebal, sehingga kelihatan mengkilat.

2. Rotan Bulu Mata

Rotan bulu matatumbuhnya berumpun, tumbuh di hutan belantara, besar batang 1 $\mathrm{cm}$, berbuku, jarak buku satu dengan yang lain $8 \mathrm{~cm}$, dalamnya berwarna kuning, 
panjangnya mencapai 20 meter dan berdaun kecil panjang.

3. Rotan Bulu Padi

Rotan bulu padi tumbuh di Hutan, tidak berumpun, batangnya berwarna abu-abu dan berduri, besarnya $1 \mathrm{~cm}$, berbuku, jarak bukunya $8 \mathrm{~cm}$, panjangnya 20-50 meter, daunnya lebar.

4. Rotan Lahoa

Rotan ini tumbuhnya berumpun, dan banyak tumbuh di hutan-hutan rimba, besar rotan ini 2-4 cm, berbuku, jarak bukunya $10 \mathrm{~cm}$, warnanya merah kekuning- kuningan panjang mencapai 2075 meter, daunnya kecil, berduri pada bagian ujung daun, bawah daun berwarna abu-abu, pelapahnya berwarna hijau.

5. Kayu Tarap

Kayu tarap (pantongan) merupakan salah satu bagian dari bahan baku yang digunakan untuk membuat tikar bidai. Ibu Roslinda menjelaskan bahwa untuk membuat karya kerajinan tikar bidai, kayu tarap ini sangat berfungsi. Tidak semua jenis kayu yang ada di hutan dapat digunakan untuk membuat tikar. Ciri-ciri dari kayu tarap ini adalah batangnya berwarna putih kekuning-kuningan, besar batangnya berukuran sedang, mempunyai ranting, dan mempunyai getah berwarna putih.

Bagian dari pohon kayu tarap ini yang digunakan untuk bahan kerajinan tikar bidai ialah kulit bagian dalam. Kayu tarap apabila sudah dibuang kulit luarnya dan diambil kulit dalamnya disebut kulit kayu pantongan, karena kulit kayu tersebut melalui proses pemukulan atau dipukul, yang dalam bahasa Dayak disebut pantongan/pangkong.

Pantongan berasal dari kulit kayu tarap yang diproses dengan cara memisahkan kulit dari batangnya kemudian kulit kayu tarap tersebut dipukul menggunakan palu (yang terbuat dari kayu), dipukul sampai pipih, setelah itu dikeringkan. Kulit pantongan yang sudah kering disimpan dan dilipat selama seminggu dalam ruangan tertutup (supaya kulit pantongan mudah dibentuk).
6. Bahan Pelengkap

Bahan pembantu dalam pembuatan kerajinan tikar bidai adalah tali yang terbuat dari kulit kayu tarap/pantongan, tali ini berfungsi sebagai tali pengikat pada bagian ujung tikar pada proses ngalape, dan tapan (dalam bahasa Dayak Bidayuh) berfungsi untuk tempat menyimpan bagian potongan rotan dan kulit kayu tarap yang sudah tidak di pergunakan.

\section{Proses Pembuatan Anyaman Bidai}

Ibu Roslinda menjelaskan, sebelum memasuki proses menganyam tahap awal, terlebih dahulu mempersiapkan bahan dan alat yang akan digunakan untuk membuat tikar bidai. Bahan yang dipersiapkan pertama adalah rotan yang siap pakai (rotan yang sudah diraut), kulit kayu pantongan yang sudah dibelah-belah sesuai ukuran yang ditentukan $(2 \mathrm{~cm})$.

Setelah semua bahan disiapkan selanjutnya mempersiapkan alat yang akan digunakan, alat tersebut berupa: kayu penjepit, kayu penahan, paku, parang dari kayu. Kayu penjepit berfungsi untuk menjepit kulit kayu tarap, kayu penahan untuk menahan bagian kulit kayu yang sudah dijepit tersebut supaya tidak lepas, paku untuk memperkuat kayu penahan, parang dari kayu untuk merapatkan anyaman pada waktu menganyam.

Tahap pertama, pasang kulit kayu tarap berjumlah tiga helai pada kayu penjepit sebagai anyaman dasar, kemudian pasang kayu penjepit dilantai dan dipaku pada bagian ujung kayu yang diberi tali supaya tidak lepas.

Tahap kedua, tarik bagian ujung kulit kayu, hal ini dilakukan supaya pada proses menganyam dilakukan, kulit kayu tidak longgar.

Tahap ketiga, ambil satu persatu helai rotan yang sudah disiapkan, dan mulailah menganyam tahap pertama, masukan rotan pada bagian kulit kayu tarap/pantongan yang sudah disejajarkan, dan seterusnya sampai terbentuklah tikar bidai.

Setelah menganyam tahap pertama dilakukan, kemudian melanjutkan anyaman tahap selanjutnya, bagian rotan yang sudah tersusun, salah satunya diangkat satu persatu, misalnya rotan pertama diangkat setelah itu rotan yang urutan ketiga, dan seterusnya, kemudian 
masukan kulit kayu pada bagian rotan yang sudah diangkat tadi, dirapatkan menggunakan tangan kemudian dipukul-pukul menggunakan parang yang terbuat dari kayu, sampai rapat dan rapi, diulangi sampai bagian ujung tikar.

Saat melanjutkan anyaman tahap pertama, menganyam dimulai dari bagian kiri menuju ke kanan, karena setiap orang menganyam tikar pasti dimulai dari kiri ke kanan. Untuk membuat tikar bidai ini membutuhkan ketelatenan, kesabaran, supaya tikar bidai yang dihasilkan rapi, dan bagus.

Ibu Roslinda menjelaskan untuk membuat tikar bidai bukanlah hal yang mudah, tikar bidai ini termasuk kerajinan tangan yang lumayan rumit, walaupun cara menganyamnya sederhana, akan tetapi membutuhkan keahlian tersendiri untuk dapat menghasilkan kerajinan yang bagus, agar diminati para pembeli. Seperti yang sudah dijelaskan, tikar bidai ini dapat menghabiskan waktu 1-2 minggu untuk menyelesaikan satu tikar dengang ukuran $2 \mathrm{~m} \quad \mathrm{x} \quad 3 \mathrm{~m}$. Selain pengolahan bahan bakunya yang lama proses pembuatannya pun sama, sehingga dari zaman dahulu sampai sekarang kerajinan tangan yang satu ini rata-rata dibuat oleh laki-laki, sebab sudah diturunkan oleh nenek moyang suku Dayak dan menjadi ciri khas dari daerah setempat.

Setelah menganyam dari tahap awal sampai tahap akhir, maka sampailah pada tahap yang disebut finishing. Finishing kerajinan tikar bidai terbagi menjadi beberapa bagian yaitu yang pertama nepo, ngalape, ngalalitn, melepas ikatan pada penjepit, melepas penjepit kayu pada kulit kayu pantongan, memasukan kulit kayu pantongan pada anyaman, membalik tikar bidai, pemotongan kulit kayu dan rotan bagian ujung anyaman yang sudah tidak dipakai.

Nepo adalah proses finishing tahap awal yaitu memasangkan satu helai kulit kayu dengan proses yang sama yaitu dianyam seperti pada waktu proses menganyam. Proses pemasangan satu helai kulit kayu ini dilakukan secara bolak balik (bagian depan tikar dan pada bagian belakang tikar), dengan tujuan supaya anyaman tikar bidai yang dibuat tidak mudah lepas dan rusak.

Selanjutnya proses finishing tahap kedua yaitu ngalape. Ngalape adalah menganyam kulit kayu tarap antara rotan satu dengan yang lain. Kulit kayu tarap yang digunakan bejumlah dua helai, dengan tujuan supaya tikar tidak mudah lepas dan tikar pun terlihat rapi. Proses ini dilakukan dengan hati-hati, sebab apabila proses ngalape tidak rapi maka anyamannya pun tidak bagus.

Tahap finishing selanjutnya ialah ngalalitn. Ngalalitn adalah mengikat anyaman dengan tali yang terbuat dari kulit kayu pantongan, dengan tujuan supaya anyaman kuat dan tidak mudah lepas. Proses pembuatan tikar bidai secara umum yang banyak menghabiskan waktu, adalah pada proses finishing karya yaitu ngalape. nepo, dan ngalalitn. Sebab proses finishing ini membutuhkan ketelitian dan kesabaran, karena lumayan rumit. Banyak pengrajin kerajinan bidai, apabila ditanya bagian mana tingkat kesulitan membuat tikar bidai ini, rata-rata menjawab pada saat finising yaitu ngalape, nepo dan ngalalitn.

Setelah proses nepo, ngalape, dan ngalaitn dilakukan selanjutnya, proses melepas tali pengikat pada kayu penjepit, setelah itu dilanjutkan melepas kayu penjepit dari kulit kayu tarap yang dipasang pada tahap menganyam pertama kali. Setelah itu proses memasukan kulit kayu tarap pada bagian anyaman, supaya rapi. Pada waktu memasukan kulit kayu pada anyaman, alat yang digunakan adalah kayu penusuk, yang bagian ujungnya diruncingkan, supaya mudah memasukan kulit kayu tersebut pada anyaman.

Selanjutnya tahap finishing paling akhir, yaitu membalik tikar bidai, dan memotong bagian ujung rotan, kulit kayu tarap. Bagian-bagian rotan dan kulit kayu pada anyaman bidai yang sudah tidak dipergunakan lagi dipotong, supaya tikar benar-benar rapi.

\section{Pengertian Pemasaran}

Menurut Louis E. Boone dan David L. Kurtz (2014: 72), "pemasaran adalah fungsi organisasional dan proses menciptakan, mengomunikasikan serta memberikan nilai kepada pelanggan dan untuk mengelola hubungn pelanggan yang dapat memberikan keuntungan bagi organisasi dan para pemangku kepentingannya (stakeholders)". Selain menjual barang dan jasa, teknik pemasaran 
membantu orang-orang untuk menyampaikan ide atau pandangan dan mendidik orang lain.

Pemasaran memengaruhi berbagai aspek organisasi dan hubungannya dengan pelanggan. Kemampuan barang atau jasa untuk memenuhi kebutuhan pelanggan disebut utilitas (utility). Fungsi produksi perusahaan menciptakan utilitas dengan mengubah bahan mentah, komponen dan input lain menjadi barang jadi atau jasa. Fungsi pemasaran menciptakan utilitas waktu, tempat dan kepemilikan. Utilitas waktu (time utility) diciptakan dengan menyediakan barang atau jasa ketika pelanggan ingin membelinya. Utilitas tempat (place utility), diciptakan dengan membuat sebuah produk tersedia dilokasi yang nyaman bagi pelanggan. Utilitas kepemilikan (ownership utility), merujuk pada transfer barang atau jasa dari penjual ke pembeli.

\section{Strategi Pemasaran}

Strategi Pemasaran adalah cara yang ditempuh perusahaan untuk merealisasikan misi, tujuan, sasaran yang telah ditentukan dengan cara menjaga dan mengupayakan adanya keserasian antara berbagai tujuan yang ingin dicapai, kemampuan yang dimiliki serta yang dimiliki serta peluang dan ancaman yang dihadapi di pasar produknya. Keserasian seperti ini memang perlu dijaga, namun tidak tertutup kemungkinan untuk berubah dan di perbaiki bilamana lingkungan pemasaran yang dihadapi mengalami perubahan. Dengan demikian, strategi pemasaran harus bersifat dinamis, fleksibel, dan memiliki kelayakan untuk dilaksanakan.

Sedangkan menurut Sofjan Assauri, M.B.A (2010: 168) “ Strategi Pemasaran adalah serangkaian tujuan dan sasaran, kebijakan dan aturan yang memberi arah kepada usaha-usaha pemasaran perusahaan dari waktu ke waktu, pada masing-masing tingkatan dan acuan serta alokasinya, terutama sebagai tanggapan perusahaan dalam menghadapi lingkungan dan keadaan persaingan yang selalu berubah".

Menurut Sofjan Assauri (2011:163), strategi pemasaran yang digunakan perusahaan ada tiga jenis yaitu:
1. Strategi pemasaran yang tidak membedabedakan pasar (Undifferentiated Marketing) artinya dengan strategi ini perusahaan ini menganggap pasar sebagai suatu keseluruhan, sehingga perusahaan hanya memperhatikan kebutuhan konsumen secara umum. Oleh karena itu perusahaan hanya menghasilkan dan memasarkan satu macam produk sja dan berusaha menarik semua pembeli dan calon pembeli dengan suatu rencana pemasaran saja.

Strategi ini bertujuan untuk melakukan penjualan secara massal, sehingga menurunkan $\rightarrow$ biaya. Perusahaan memusatkan perhatiannya pada seluruh konsumen dan kebutuhannya, serta merancang produk yang dapat menarik sebanyak mungkin para konsumen tersebut.

Salah satu keuntungan strategi ini adalah kemampuan perusahaan untuk menekan biaya sehingga dapat lebih ekonomis. Sebaliknya, kelemahannya adalah apabila banyak perusahaan lain juga menjalankan strategi pemasaran yang sama, maka akan terjadi persaingan yang tajam untuk menguasai pasar tersebut. Akibatnya, strategi ini dapat menyebabkan kurang menguntungkan usaha-usaha pemasaran perusahaan, karena banyak dan makin tajamnya persaingan.

2. Strategi pemasaran yang membedabedakan pasar (Differentiated Marketing), artinya yaitu dengan strategi ini, perusahaan hanya melayani kebutuhan bebrapa kelompok konsumen tertentu dengan jenis produk tertentu pula. Jadi perusahaan atau produsen menghasilkan dan memasarkan produk yang berbedabeda untuk tiap segmen pasar. Dengan perkataan lain, perusahaan atau produsen menawarkan berbagai variasai produk, yang disesuaikan dengan kebutuhan dan keinginan kelompok konsumen atau pembeli yang berbeda-beda, dengan program pemasaran yang tersendiri diharapkan dapat dicapai tingkat penjualan yang tertinggi dalam masing-masing segmen pasar tersebut. 
Perusahaan yang menggunakan strategi ini bertujuan untuk mempertebal kepercayaan kelompok konsumen tertentu terhadap produk yang dihasilkan dan pasarkan, sehingga pembeliannya akan dilakukan berulang kali. Dengan demikian diharapkan penjualan perusahaan akan lebih tinggi dan kedudukan produk perusahaan akan lebih kuat atau mantap di segmen pasar. Keuntungan strategi pemasaran ini, penjualan dapat diharapkan akan lebih tinggi dengan posisi produk yang lebih baik di setiap segmen pasar, dan total penjualan perusahaan akan dapat ditingkatkan dengan bervariasinya produk yang ditawarkan. Kelemahan strategi ini adalah, terdapat kecenderungan biaya akan lebih tinggi karena kenaikan biaya produksi untuk modifikasi produk, biaya administrasi, biaya promosi, dan biaya investasi.

3. Strategi pemasaran yang terkonsentrasi (Concentrated Marketing), artinya yaitu dengan strategi ini, perusahaan mengkhususkan pemasaran produknya dalam beberapa segmen pasar, dengan pertimbangan keterbatasan sumber daya perusahaan. Dalam hal ini perusahaan produsen memilih segmen pasar tertentu dan menawarkan produk yang sesuai denga kebutuhan dan keinginan kelompok konsumen yang ada pada segmen pasar itu, yang tentunya lebih spesifik.

Keuntungan menggunakan strategi ini, perusahaan dapat diharapkan akan memperoleh kedudukan atau posisi yang kuat di dalam segmen pasar tertentu yang dipilih. Hal ini karena, perusahaan akan mempunyai pengetahuan dan pengalaman yang lebih baik dalam melakukan pendekatan dari segmen pasar yang dilayaninya. Di samping itu perusahaan memperoleh keuntungn karena spesialisasi dalam produksi, distribusi dan usah promosi, sehingga apabila segmen pasar dipilih secara tepat, akan dapat memungkinkan berhasilnya usaha pemasaran produk perusahaan tersebut. Kelemahan strategi pemasaran ini adalah perusahaan akan meghadapi risiko yang besar bila hanya tergantung pada satu atau beberapa segmen pasar saja. Hal ini karena, kemungkinan terjadinya perubahan selera para konsumen, atau peningkatan kemampuan daya saing perusahaan lain yang dapat melebihi kemampuan perusahaan ini dalam melayani pasar secara baik dan efektif.

Dalam konsep pemasaran dewasa ini, dikenal salah satu konsep pemasaran yaitu marketing mix (bauran pemasaran) yang merupakan variabel-variabel yang dipakai oleh suatu perusahaan sebagai salah satu sarana untuk memenuhi kebutuhan dan keinginan konsumen serta merupakan alat bagi perusahaan dalam mencapai tujuannya.

Marketing mix mempunyai dua faktor yaitu faktor eksternal dan internal. Faktor eksternal yaitu faktor diluar jangkauan perusahaan yang antara lain terdiri dari pesaing, keadaan perekonomian, dan lingkungan sosial budaya. Sedangkan faktor internalnya yaitu variabelvariabel yang terdapat dalam marketing mix seperti: Produk (product), Harga (Price), Promosi (promotion), Tempat (Place), Orang (People), Bukti fisik (Physical evidence), dan Proses (process).

Menurut Sofjan Assauri (2010,198) "Marketing mix merupakan himpuanan variabel yang dapat dikendalikan dan digunakan oleh perusahaan untuk mempengaruhi tanggapan konsumen dalam pasar sasarannya".

Dari definisi-definisi di atas maka dapat diambil kesimpulan bahwa marketing mix merupakan kombinasi dari berbagai macam variabel. Variabel-variabel tersebut dapat dikelompokan menjadi empat kelompok utama yang dikenal dengan $7 \mathrm{p}$ :

1. Produk (Product)

2. Harga (Price)

3. Promosi (Promotion)

4. Tempat (Place)

5. Orang (People)

6. Bukti Fisik (Physical Evidence)

7. Proses (Process)

Secara garis besar ketujuh variabel tersebut dapat dijelaskan melalui penjelasan masingmasing sebagai berikut : 
1) Produk (Product)

Menurut Philip Kotler yang dimaksud dengan "Produk adalah sesuatu yang bisa ditawarkan ke pasar untuk mendapatkan perhatian, pembelian, pemakaian, atau konsumsi yang dapat memenuhi keinginan dan kebutuhan".

2) Harga (Price)

Menurut Philip Kotler yang dimaksud dengan "Harga adalah sejumlah uang yang dibebankan untuk sebuah produk atau jasa. Secara lebih luas, harga adalah keseluruhan nilai yang ditukar konsumen untuk mendapatkan keuntungan dari kepemilikan terhadap sebuah produk dan jasa".

3) Promosi (Promotion)

Menurut Philip Kotler yang dimaksud dengan "Promosi meliputi semua aktifitas perusahaan menyanggupi untuk berkomunikasi dan mempromosikan produk target pasar".

4) Tempat (Place)

Menurut Philip Kotler yang dimaksud dengan "Tempat atau distribusi adalah berbagai kegiatan yang dilakukan perusahaan untuk membuat produknya mudah diperoleh dan tersedia untuk konsumen sasaran. Tempat atau distribusi dapat dilihat sebagai kumpulan organisasi yang saling bergantung sati sama lainnya yang terlibat dalam proses penyediaan produk atau pelayanan".

5) Orang (People)

Orang adalah jasa yang diberikan oleh seseorang dimana diseleksi, dilatih, dan motovasi sehingga dapat memberikan perbedaan yang besar dalam kepuasan konsumen.

Kebutuhan konsumen terhadap karyawan berkinerja tinggi akan menyebabkan konsumen puas dan loyal. Kemampuan yang baik dari seseorang akan menjadi kompetensi dasar dalam internal perusahaan dan pencitraan yang baik diluar.

6) Bukti Fisik ( Physical Evidence)

Physical Evidence adalah lingkungan fisik tempat jasa diberikan tempat dimana pelanggan dan perusahaan melakukan interaksi serta komponen lain yang membantu meningkatkan pelayanan jasa yang diberikan.

7) Proses (Process)

Proses adalah semua prosedur aktual, mekanisme, dan aktifitas dengan mana jasa yang disampaikan merupakan sistem penyajian atau operasi jasa.

Proses mutu layanan jasa sangat bergantung pada proses penyampaian jasa kepada konsumen karena penggerak perusahaan jasa adalah karyawan itu sendiri, maka untuk menjamin mutu layanan, seluruh operasional perusahaan harus dijalankan sesuai ddengan sistem dan prosedur yang terstandarisasi oleh karyawan yang berkompetensi, berkomitmen, dan loyal terhadap perusahaan tempat bekerja.

\section{METODE PENELITIAN}

Dalam penelitian ini, metode yang digunakan peneliti adalah metode analisis deskriftif, dengan mendeskripsikan suatu gejala peristiwa atau kejadian secara sistematis dan akurat mengenai sifat-sifat populasi atau daerah tertentu atau untuk mengetahui keberadaan variabel mandiri, baik hanya satu variabel atau lebih (variabel yang berdiri sendiri atau variabel bebas) tanpa membuat perbandingan variabel itu sendiri dan mencari hubungan dengan variabel lain (Sugiyono, 2017: 35). Penelitian ini bersifat kuantitatif karena meneliti pada populasi atau sampel tertentu, pengumpulan data menggunakan instrumen penelitian, analisis data atau statistik dengan tujuan untuk menguji hipotesis yang telah ditetapkan (Sugiyono, 2017: 8).

\section{Metode Penelitian}

Metode yang digunakan dalam penelitian ini adalah metode deskriftif yang bertujuan untuk mengetahui sifat serta hubungan yang lebih mendalam antara dua variabel dengan cara mengamati aspek-aspek tertentu secara lebih spesifik untuk memperoleh data yang sesuai dengan masalah yang ada dengan tujuan penelitian, di mana data tersebut diolah, dianalisis dan diproses lebih lanjut dengan 
dasar teori-teori yang ada sehingga data tersebut dapat ditarik kesimpulannya.

\section{Subjek Penelitian}

Subjek dalam penelitian ini merupakan penelitian populasi wilayah desa Jagoi sebanyak 100 dan sampel yang diambil adalah $50 \%$ dari populasi yaitu 50 sampel. Sampel adalah unsur atau bagian tertentu dari populasi guna mewakili seluruh populasi-populasi. Menurut Margono (2010: 121), "sampel adalah sebagai bagian dari populasi. Sampel yang diambil adalah populasi dari jumlah msayarakat desa Jagoi . Oleh karena itu, peneliti memutuskan untuk penarikan sampel dalam penelitian dilakukan dengan cara purposive sampling.

\section{Teknik Pengumpulan Data}

Menurut Wiratna Sujarweni (2014: 74) “teknik pengumpulan data merupakan cara yang dilakukan peneliti untuk mengungkap informasi kualitatif dari responden sesuai lingkup penelitian". Teknik pengumpulan data yaitu dengan cara penelitian lapangan atau survei, sedangkan alat yang digunakan untuk mengumpulkan data di antaranya adalah :

1. Kuesioner adalah suatu teknik pengumpulan informasi yang memungkinkan analis mempelajari sikap-sikap, keyakinan, perilaku dan karakteristik beberapa orang terutama di dalam organisasi yang bias terpengaruh oleh sistem yang diajukan atau sistem yang sudah ada.

2. Teknik komunikasi langsung yaitu dengan mengadakan hubungan langsung pada sumber data yang dianggap mengetahui permasalahan yang diteliti yaitu melalui wawancara dengan pemilik usaha kerajinan anyaman bidai, karyawan dan masyarakat di desa Jagoi.

3. Teknik komunikasi tidak langsung yaitu cara mengumpulkan data dengan memerlukan bantuan alat komunikasi yang fungsinya sebagai media perantara sebagai pengantar pesan atau informasi agar sampai ke komunikan atau penerima pesan.

4. Dokumentasis ÉP.yaitu proses pengumpulan data dan pengambilan data berdasarkan tulisan-tulisan berbentuk catatan, buku, dokumen atau arsip-arsip milik pengusaha kerajinan anyaman bidai, ataupun tulisantulisan dan berkas-berkas yang memiliki relevansi dengan pembahasan peneliti ini.

\section{Analisis Data Penelitian}

Data yang terkumpul diuji dan dianalisis dengan Statistical Product and Service Solution (SPSS). Metode analisis data menggunakan, pengujian instrument, pengolahan data, dan pengujian hipotesis.

1. Pengujian Instrument

a. Uji Validitas Data

Validitas adalah suatu ukuran yang menunjukkan tingkat-tingkat kevalidan atau kesahihan suatu instrument. Marsi Singarimbun (2017:33), mengatakan bahwa "untuk mengetahui setiap butir pertanyaan pada tiap-tiap variabel dinilai valid atau tidak dilakukan dengan membandingkan $r$ hitung dengan $r$ tabel antara nilai skor item yang di uji dengan jumlah seluruh skor yang dikaji”.

b. Uji Reliabilitas

Dataisepeliabilitas mengacu pada konsistensi skor atau jawaban dari pelaksanaan satu instrumen lain dan apabila dilakukan pengukuran berkali-kali terhadap suatu unit akan menghasilkan ouput yang sama. Reliabilitas suatu variabel dikatakan cukup baik jika memiliki nilai koefisien reliabilitas (r11) lebih besar dari 0,600. Uji reliabilitas instrument dilakukan dengan tujuan untuk mengetahui konsistensi dari instrument sebagai alat ukur, sehingga hasil suatu pengukuran dapat dipercaya.

2. Uji Asumsi Klasik

a. Uji Normalitas

Uji normalitas bertujuan untuk menguji apakah dalam model regresi variabel dependen, variabel independen atau keduanya mempunyai distribusi normal atau tidak. Model regresi yang baik adalah distribusi data normal atau mendekati normal.s. mendeteksi normalitas dengan melihat penyebaran data (titik) pada sumbu diagonal dari grafik. Dasar pengambilan keputusan dalam uji normalitas adalah:

1. Jika data menyebar disekitar garis diagonal dan mengikuti arah garis diagonal, maka regresi memenuhi asumsi normalitas. 
2. Jika data menyebar dari garis diagonal dan atau tidak mengikuti arah garis diagonal, maka model regresi tidak ispepmemenuhi asumsi normalitas. SEEP

3. Uji korelasi

Berikut ini adalah bagian dari perhitungan uji korelasi yang terdiri dari uji korelasi (r) dan uji determinasi (r2) Koefiseian Korelasi

Koefisien korelasi merupakan analisa statistik ini bertujuan untuk mengetahui ada atau tidaknya hubungan antara 2 (dua) variabel, yaitu variabel bebas dan variabel terikat. Koefisien korelasi bertujuan untuk mengetahui sejauh mana hubungan antara kedua variabel (independen dan dependen). ${ }^{-i}$ Pij Ketentuan dari uji korelasi adalah sebagai berikut:

a. Jika nilai $\mathrm{r}>0$, artinya telah terjadi hubungan positif yaitu isEp: variabel $X$ (independen), maka makin besar pula nilai variabel Y (dependen) atau makin kecil nilai variabel $X$ (independen) maka makin kecil pula nilai variabel Y (dependen) . ín

b. Jika nilai $\mathrm{r}<0$, artinya telah terjadi hubungan yang negatif, yaitu makin kecil nilai variabel $X$ (independen), maka akan makin kecil nilai variabel Y (dependen) atau makin kecil nilai variabel $X$ (independen), maka semakin kecil nilai variabel $Y$ (dependen). is.ep:

c. Jika nilai $r=1$, telah terjadi hubungan sempurna antara variabel $\mathrm{X}$ (indepeden) dengan variabel Y (dependen).

4. Uji Hipotesis

Pengujian hipotesis dilakukan dengan menggunakan uji regresi linier sederhana dengan bantuan program SPSS versi 24 digunakan untuk menguji apakah terdapat pengaruh antara variabel independen terhadap variabel dependen. Adapun dalam penelitian ini menguji hipotesis secara parsial:isepa. Uji t (uji parsial) Untuk mengetahui ada atau tidak pengaruh masing-masing variabel dependen secara individual (parsial) terhadap variabel dependen. Hasil uji t hitung ini pada output perangkat lunak, dapat dilihat pada tabel coefficient level of significance yang digunakan sebesar 5\% (a) $=0,05$. Apabila $\mathrm{t}$ hitung > t tabel maka Ho ditolak dan $\mathrm{Ha}$ diterima, artinya variabel independen secara parsial mempunyai pengaruh yang signifikan terhadap variabel dependen. Apabila $t$ hitung < t tabel maka Ho diterima dan Ha ditolak, artinya variabel independen secara parsial tidak mempunyai pengaruh yang signifikan terhadap variabel dependen. Analisis ini juga dapat memberikan informasi tentang kontribusi masingmasing variabel independen terhadap variabel dependen dengan melihat $\mathrm{r} 2$ nya. Variabel yang memenuhi $r 2$ terbesar adalah variabel independen yang mempunyai pengaruh dominan.

5. Analisis Regresi Linier Sederhana

a.Persamaan Regresi Linier Sederhanas regresi linier dimaksudkan untuk mengetahui seberapa besar tingkat pengaruh antara variabel bebas (independen) dengan variabel terikat (dependen). Metode ini juga bisa digunakan sebagai prediksi, sehingga dapat diperkirakan antara baik atau buruknya suatu variabel $\mathrm{X}$ terhadap terhadap naik turunya suatu tingkat variabel $\mathrm{Y}$, begitu pun sebaliknya. Rumus regresi linier sederhana:

$\mathrm{Y}=\mathrm{a}+\mathrm{bX}$

Dimana:

$\mathrm{Y}$ : Nilai yang diprediksikan

$\mathrm{X}$ : Nilai variabel independen atau bila harga $X=0 \mathrm{~b}$ : koefisien regresi.

langkah selanjutnya adalah melakukan pengujian dan pembuktian terhadap hipotesis yang telah dibuat. Pembuktian ini melalui perhitungan dengan menggunakan perangkat lunak.

b. Uji Determinasi (R2) SLepijKoefisien determinasi (R2) bertujuan untuk mengetahui seberapa besar kemampuan variabel independen menjelaskan variabel dependen. Dalam output SPSS, koefisien determinasi terletak pada tabel Model Summary dan tertulis R Square.

Nilai R2 sebesar 1, berarti pengaruh variabel dependen seluruhnya dijelaskan oleh variabel independen dan tidak ada faktor lain yang menyebabkan pengaruh variabel dependen. Jika nilai R2 berkisar 0 sampai dengan 1, berarti semakin kuat kamampuan variabel 
dependen dapat menjelaskan pengaruh variabel dependen.

ancangan kegiatan, ruang lingkup atau objek, Bahan dan alat utama, tempat, teknik pengumpulan data, definisi operasional variabel penelitian, dan teknik analisis.

\section{HASIL DAN PEMBAHASAN}

A. Variabel Yang Memengaruhi Strategi Pemasaran Terhadap Penjualan Anyaman Bidai Desa Jagoi Kecamatan Jagoi Babang Kabupaten Bengkayang.

a. Uji Validitas dan Reabilitas

1) Uji validitas

Uji Validitas dilakukan kepada 50 responden yang memenuhi kriteria yang telah ditentukan. Pernyataan dinyatakan valid atau layak apabila r-hitung > rtabel. Pada $\mathrm{r}$ - tabel di peroleh $\mathrm{n}=50$ pada a 5\% sebesar 0,312 . Hasil uji validitas yang dilakukan dengan menggunakan program SPSS versi 24.0, berdasarkan hasil uji validitas yang dilakukan terhadap 50 orang responden menghasilkan 30 variabel yang dinyatakan valid. Hal ini dapat disimpulkan dengan melihat bahwa setiap variabel memiliki $r$-hitung lebih besar dibandingkan r-tabel. Hal ini mengindikasikan bahwa seluruh pernyataan yang dibuat dinilai layak dan dapat digunakan untuk keperluan penelitian.

\section{2) Uji Realibilitas}

Realibilitas suatu instrumen menunjukkan tingkat kehandalan instrumen dalam mengungkap data yang bisa dipercaya (Arikunto, 2014: 222). Untuk menguji reliabilitas instrumen strategi pemasaran dan penjualan anyaman bidai digunakan rumus Alpha Cronbach (Sugiyono, 2015: 365), karena rumus Alpha Cronbach digunakan untuk mencari reliabilitas instrumen yang skornya bukan 0 dan 1 , misalnya angket atau soal bukan uraian.

Uji realibilitas dalam penelitian ini menggunakan bantuan komputer program SPSS versi 24.0 dengan uji keterandalan teknik Alpha Cronbach. Untuk menginterpretasikan koefisien reliabilitas digunakan kategori menurut Sugiyono (2015: 184) dapat dilihat pada tabel 2 sebagai berikut:

Tabel 2

Interpretasi Koefisien Korelasi (r)

\begin{tabular}{|c|c|}
\hline \multicolumn{2}{|c|}{ Interpretasi Koefisien Korelasi (r) } \\
\hline Interval Koefisien & Tingkat Hubungan \\
\hline $0,00-0,199$ & Sangat Rendah \\
\hline $0,20-0,399$ & Rendah \\
\hline $0,40-0,599$ & Sedang \\
\hline $0,60-0,799$ & Kuat \\
\hline $0,80-1,000$ & Sangat Kuat \\
\hline
\end{tabular}




\begin{abstract}
Kriteria
pengambilan

keputusan untuk menentukan reliabel atau tidak bila koefisein $r$ lebih besar atau sama dengan 0,600 maka item tersebut dikatakan reliabel. Apabila koefisien $\mathrm{r}$ lebih
\end{abstract}

kecil dari 0,600 maka item tersebut tidak reliabel. Hasil uji reabilitas

untuk instrumen strategi pemasaran diperoleh dan disajikan dalam gambar 1 di bawah ini

\section{Gambar 1 \\ Hasil Uji Realibilitas Instrumen Strategi Pemasaran}

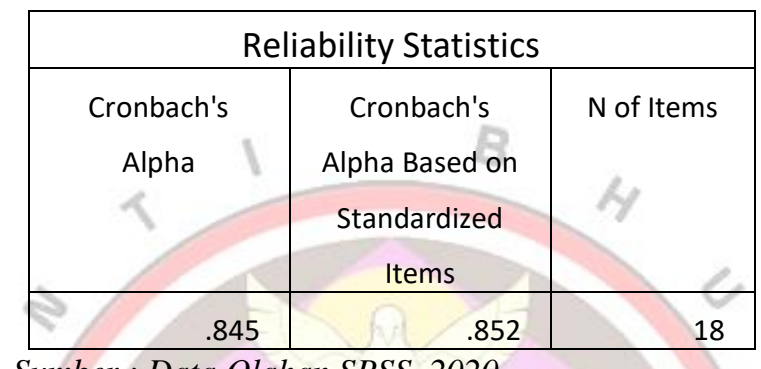

Sumber : Data Olahan SPSS, 2020

Sedangkan Hasil uji reabilitas untuk instrumen penjualan diperoleh dan disajikan dalam gambar 2 di bawah ini:

Gambar 2

Hasil Uji Realibilitas Instrumen Penjualan

Sumber : Data Olahan SPSS, 2020

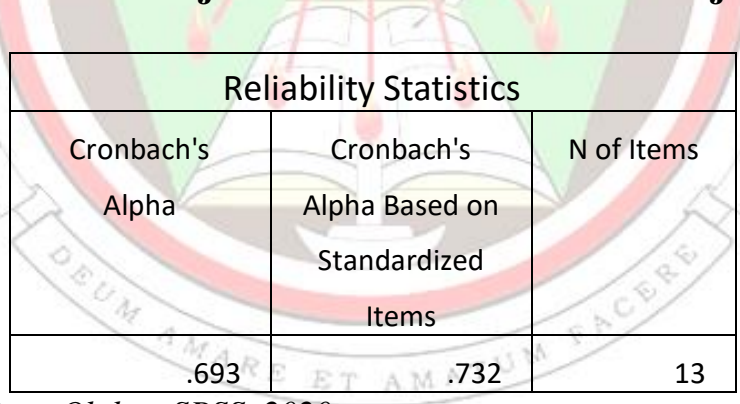

Hasil yang diperoleh dapat disajikan

kedalam tabel 2 di bawah ini:

Tabel 2

Hasil Uji Realibilitas dan Interpretasi

\begin{tabular}{|l|l|l|}
\hline \multicolumn{1}{|c|}{ Variabel } & \multicolumn{1}{c|}{ Nilai Reliabilitas } & \multicolumn{1}{c|}{ Interpretasi } \\
\hline $\begin{array}{l}\text { Strategi } \\
\text { Pemaasaran }\end{array}$ & 0,852 & Sangat Kuat \\
\hline Penjualan & 0,732 & Kuat \\
\hline
\end{tabular}

Sumber : Data Olahan SPSS, 2020 
Berdasarkan hasil tersebut, diketahui bahwa nilai alpha sebesar 0,852 , kemudian nilai ini dibandingkan dengan nilai 0,600 , dapat disimpulkan bahwa alpha $=0,852>$ 0,600 yang artinya butir-butir Kuesioner strategi pemasaran dikatakan reliabel atau terpercaya sebagai alat pengumpul data dalam penelitian. Hal ini juga berlaku untuk butirbutir kuesioner penjualan yang memiliki nilai alpha 0,732 > 0,600 yang artinya terpercaya sebagai alat pengumpul data dalam penelitian ini.

\section{b. Uji Asumsi Klasik}

\section{1). Uji Normalitas}

Uji normalitas digunakan untuk mengetahui data yang akan dianalisis berdistribusi normal atau tidak. Secara fundamental, data yang berdistribusi normal dapat diketahui melalui bentuk histogram seperti lonceng.

Uji Normalitas Kolmogorov Smirnov adalah uji yang dilakukan untuk mengetahui sebaran data acak dan spesifik pada suatu populasi (Chakravart, Laha, and Roy, 1967). Berdasarkan pengujian yang dilakukan National Institute of Standars and Technology, uji kolmogorov smirnov menghasilkan performa yang baik untuk ukuran data 20-1000. Namun dalam penelitian pada umumnya, pengujian kolmogorov smirnov masih digunakan untuk sampel data yang berukuran lebih dari 2000 sampel. Sehingga disarankan untuk menggunakan uji kolmogorov smirnov untuk data di atas 50 sampel $(20 \leq \mathrm{N} \leq 1000)$. Dalam pengujian, suatu data dikatakan berdistribusi normal apabila nilai signifikansi $>0.05$ ( sig. >0.05).

Uji Normalitas Shapiro Wilk adalah uji yang dilakukan untuk mengetahui sebaran data acak suatu sampel kecil. Dalam 2 seminar paper yang dilakukan Shapiro, Wilk tahun 1958 dan Shapiro, Wilk, Chen 1968 digunakan simulasi data yang tidak lebih dari 50 sampel. Sehingga disarankan untuk menggunakan uji shapiro wilk untuk sampel data kurang dari 50 sampel $(\mathrm{N}<50)$. Dalam pengujian, suatu data dikatakan berdistribusi normal apabila nilai signifikansi $>0.05$ (sig. $>0.05$ ). Dalam penelitian ini pengujian normalitas menggunakan metode Shapiro Wilk. Hasil pengujian dapat dilihat pada tabel dibawah 4 dibawah ini :

Tabel 4

Uji Normalitas Kolmogorov-Smirnova dan Shapiro-Wilk

\begin{tabular}{|c|c|c|c|c|c|c|}
\hline \multicolumn{7}{|c|}{ Tests of Normality } \\
\hline & \multicolumn{3}{|c|}{ Kolmogorov-Smirnov } & \multicolumn{3}{|c|}{ ET A M A Shapiro-Wilk } \\
\hline & Statistic & $\mathrm{df}$ & Sig. & Statistic & $d f$ & Sig. \\
\hline $\mathrm{Y}$ & .164 & 50 & .087 & .915 & 50 & .067 \\
\hline $\mathrm{x}$ & .099 & 50 & $.200^{*}$ & .978 & 50 & .601 \\
\hline \multicolumn{7}{|c|}{ *. This is a lower bound of the true significance. } \\
\hline & s Sign & Correc & & & & \\
\hline
\end{tabular}

Sumber : Data Olahan SPSS, 2020 
Nilai signifikansi (p) pada uji shapiro-wilk adalah untuk $\mathrm{Y}$ (Penjualan) sebesar 0,005 artinya lebih besar $0,067<0,05$ sinifikansi ( $p$ $>0,05)$, sehingga berdasarkan uji normalitas shapiro-wilk data dikategorikan berdistribusi normal. Sedangkan untuk X (Strategi Pemasaran) sebesar 0,601 ( $\mathrm{p}>0,05)$, sehingga berdasarkan uji normalitas shapirowilk data berdistribusi normal.

Ada beberapa cara mendeteksi normalitas dengan melihat penyebaran data (titik) pada sumbu diagonal dari grafik. Dasar pengambilan keputusan dalam uji normalitas dapat dilihat dari hasil scater plot pada gambar 3 dan gambar 4 dibawah ini :

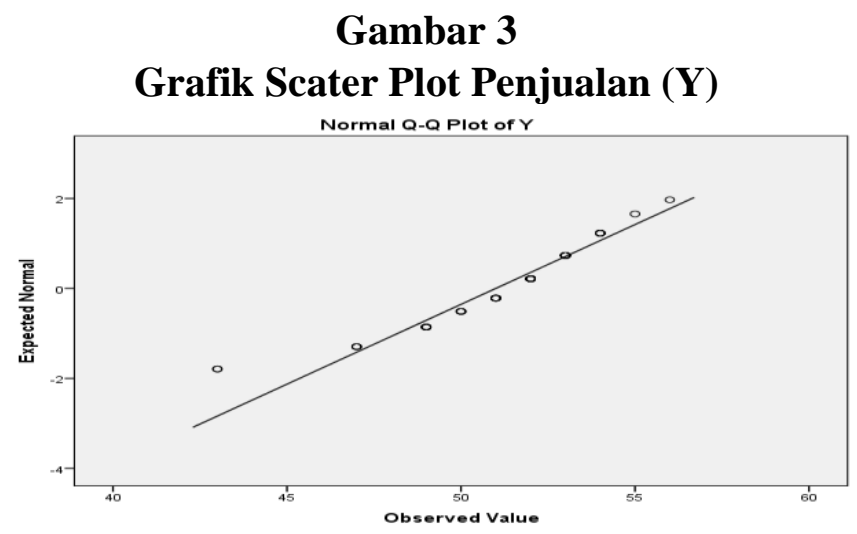

Sumber: Data Olahan SPSS, 2020

\section{Gambar 4}

Grafik Scater Plot Strategi Pemasaran (X)

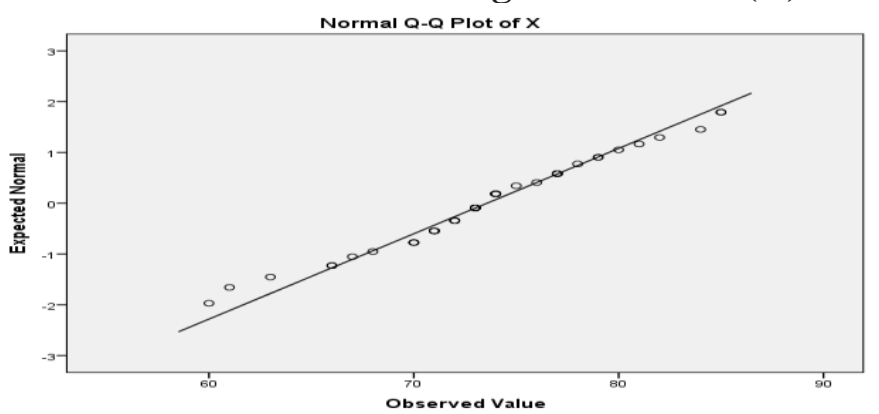

Sumber: Data Olahan SPSS, 2020

Berdasarkan gambar 3 dan gambar 4 tentang penyebaran scater plot, data berdistribusi menyebar disekitar garis diagonal dan mengikuti arah garis diagonal, maka regresi memenuhi asumsi normalitas.

2). Uji korelasi

Dari hasil analisis korelasi sederhana

(r) didapat korelasi antara strategi pemasaran dengan penjualan (r) adalah 0,909 . Hal ini menunjukkan bahwa terjadi hubungan yang kuat antara strategi pemasaran dengan penjualan. Sedangkan arah hubungan adalah positif karena nilai $r$ positif, berarti semakin tinggi strategi pemasaran maka semakin meningkatkan hasil penjualan.

Uji signifikansi koefisien korelasi digunakan untuk menguji apakah hubungan yang terjadi itu berlaku untuk populasi (dapat digeneralisasi). Misalnya dari kasus di atas populasinya adalah 
masyarakat desa Jagoi dan sampel yang diambil dari kasus di atas adalah 50 orang masyarakat desa Jagoi, jadi kesimpulan yang diambil dapat berlaku untuk populasi, yaitu seluruh masyarakat yang ada di desa Jagoi Babang. Dari hasil olahan dengan SPSS 24.0, diperoleh hasil sebagai berikut :

\section{Tabel 5}

\section{Hasil Uji kolerasi Strategi Pemasaran (X) dan Penjualan (Y)}

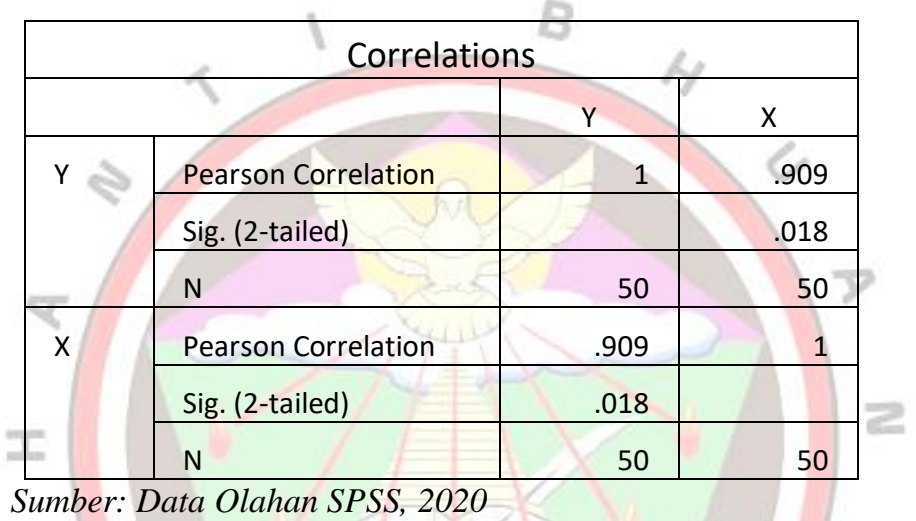

Langkah-langkah pengujian sebagai berikut:

Ho : Tidak ada pengaruh secara signifikan antara strategi pemasaran dengan penjualan $\mathrm{Ha}$ : Ada pengaruh secara signifikan antara strategi pemasaran dengan penjualan.

Dalam penelitian ini menggunakan uji dua sisi dengan tingkat signifikansi $a=5 \%$. (uji dilakukan 2 sisi karena untuk mengetahui ada atau tidaknya hubungan yang signifikan, jika 1 sisi digunakan untuk mengetahui hubungan lebih kecil atau lebih besar). Tingkat signifikansi dalam hal ini berarti kita mengambil risiko salah dalam mengambil keputusan untuk menolak hipotesa yang benar sebanyak-banyaknya 5\% (signifikansi 5\% atau 0,05 adalah ukuran standar yang sering digunakan dalam penelitian)

Kriteria Pengujian:

Ho diterima jika Signifikansi $>0,05$

Ho ditolak jika Signifikansi $<0,05$

Dengan membandingkan signifikansi, Nilai signifikansi $0,018<0,05$, maka Ho ditolak. Hal ini disebabkan karena nilai Signifikansi
0,018 lebih kecil 0,05 maka Ho ditolak, artinya bahwa ada pengaruh secara signifikan antara strategi pemasaran dengan penjualan. Karena koefisien korelasi nilainya positif, maka berarti strategi pemasaran berpengaruh positif dan signifikan terhadap penjualan. Jadi dalam kasus ini dapat disimpulkan bahwa strategi pemasaran berpengaruh positif terhadap penjualan anyaman bidai kerajinan tangan desa Jagoi.

3). Uji Hipotesis

Pengujian hipotesis dilakukan dengan menggunakan uji regresi linier sederhana dengan bantuan program SPSS versi 24 digunakan untuk menguji apakah terdapat pengaruh antara variabel independen terhadap variabel dependen. Adapun dalam penelitian ini menguji hipotesis secara parsial. Uji t (uji parsial) Untuk mengetahui ada atau tidak pengaruh masing-masing variabel dependen secara individual (parsial) terhadap variabel dependen. Dari hasil olahan dengan SPSS 24.0, di peroleh hasil sebagai berikut: 


\begin{tabular}{|c|c|c|c|c|c|c|}
\hline \multicolumn{7}{|c|}{ Coefficients $^{a}$} \\
\hline & & \multicolumn{2}{|c|}{ Unstandardized Coefficients } & \multirow{3}{*}{$\begin{array}{c}\text { Standardized } \\
\text { Coefficients } \\
\text { Beta }\end{array}$} & \multirow{3}{*}{$\begin{array}{l}\mathrm{t} \\
7.860\end{array}$} & \multirow{3}{*}{$\begin{array}{l}\text { Sig. } \\
.000\end{array}$} \\
\hline \multicolumn{2}{|c|}{ Model } & B & Std. Error & & & \\
\hline & (Constant) & 43.545 & 5.540 & & & \\
\hline 1 & $x$ & .101 & .075 & .909 & 3.466 & .018 \\
\hline
\end{tabular}

Sumber: Data Olahan SPSS, 2020

Cara pengambilan keputusan

1. $\mathrm{t}$ hitung $<\mathrm{t}$ tabel Ho diterima ; $\mathrm{t}$ hitung $>\mathrm{t}$ tabel Ha diterima

2. Probabilitas $>0.05$ Ho diterima ; probabilitas $<0.05$ Ha diterima

dari hasil output SPSS di peroleh :

t hitung $=3,466$

t tabel $(2-1)(3-1)=2.026(\mathrm{df}: 2)$

b. Ada pengaruh antara strategi pemasaran dengan penjualan anyaman bidai kerajinan tangan desa Jagoi.

2. Variabel Yang Berpengaruh Terhadap Kendala Penjualan Yang Dihadapi Oleh Pengrajin Anyaman Bidai Desa

a. Persamaan Regresi Linier Sederhana Metode regresi linier dimaksudkan untuk mengetahui seberapa besar tingkat pengaruh antara variabel bebas (independen) dengan variabel terikat (dependen). Metode ini juga bisa digunakan sebagai prediksi, sehingga dapat diperkirakan antara baik atau buruknya suatu variabel $\mathrm{X}$ terhadap terhadap naik turunnya suatu tingkat dengan $\alpha=0.05$

Keputusan :

a. 3,466> 2.026 (Ha diterima, Apabila $\mathrm{t}$ hitung > t tabel maka Ho ditolak dan $\mathrm{Ha}$ diterima, artinya variabel independen secara parsial mempunyai pengaruh yang signifikan terhadap variabel dependen)

\section{Jagoi Kecamatan Jagoi Babang Kabupaten Bengkayang.}

variabel Y, begitu pun sebaliknya. Rumus regresi linier sederhana:

$\mathrm{Y}=\mathrm{a}+\mathrm{bX}$

Di mana:

Y : Nilai yang diprediksikan

$\mathrm{X}$ : Nilai variabel independen

a : konstanta atau bila penjualan

$\mathrm{X}=0 \mathrm{~b}$ : koefisien regresi.

Dari hasil olahan dengan SPSS 24 untuk hasil uji regresi linier tersebut dapat disajikan pada tabel 7 di bawah ini : 
Tabel 7

Penilaian Ketepatan Model Regresi Sederhana

\begin{tabular}{|l|l|l|l|}
\hline \multicolumn{4}{|c|}{ Variables Entered/Removed $^{\mathrm{a}}$} \\
\hline Model & $\begin{array}{c}\text { Variables } \\
\text { Entered }\end{array}$ & $\begin{array}{c}\text { Variables } \\
\text { Removed }\end{array}$ & Method \\
\hline 1 & $\mathrm{X}^{\mathrm{b}}$ & & Enter \\
\hline a. Dependent Variable: $Y$ &. \\
\hline \multicolumn{3}{|l}{ b. All requested variables entered. } \\
\hline
\end{tabular}

Sumber: Data Olahan SPSS, 2020

Nilai signifikansi $0,018<0,05$, maka Ho ditolak. Hal ini disebabkan karena nilai Signifikansi 0,018 lebih kecil 0,05 maka
Ho ditolak, artinya bahwa ada pengaruh secara signifikan antara strategi pemasaran dengan penjualan seperti pada tabel 8 berikut:

Tabel 8

\section{Hasil Uji Regresi Linier Sederhana}

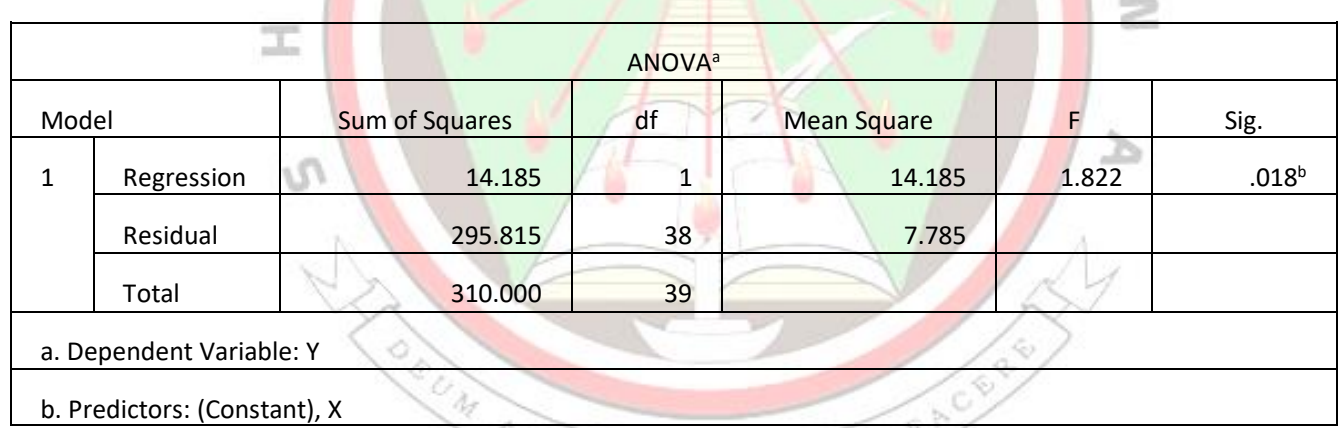

Sumber: Data Olahan SPSS, 2020

Dari hasil olahan tabel coefficients diperoleh model persamaan regresi dengan koefisien konstanta dan koefisien variabel yang ada dikolom unstandardized
Coefficients B seperti yang telah disajikan pada tabel 9 berikut ini :

Tabel 9

Hasil Uji Coefficients (Uji t)

\begin{tabular}{|c|c|c|c|c|c|c|}
\hline \multicolumn{7}{|c|}{ Coefficients $^{a}$} \\
\hline & & \multicolumn{2}{|c|}{ Unstandardized Coefficients } & \multirow{3}{*}{$\begin{array}{c}\text { Standardized } \\
\text { Coefficients } \\
\text { Beta }\end{array}$} & \multirow{3}{*}{$\begin{array}{l}\mathrm{t} \\
7.860 \\
\end{array}$} & \multirow{3}{*}{$\begin{array}{l}\text { Sig. } \\
.000\end{array}$} \\
\hline \multicolumn{2}{|c|}{ Model } & $\mathrm{B}$ & Std. Error & & & \\
\hline & (Constant) & 43.545 & 5.540 & & & \\
\hline 1 & $x$ & .101 & .075 & .909 & 1.350 & .018 \\
\hline
\end{tabular}

Sumber: Data Olahan SPSS, 20 
Langkah selanjutnya adalah melakukan pengujian dan pembuktian terhadap hipotesis yang telah dibuat. Hipotesis pengujian :

Ho : Tidak ada pengaruh secara signifikan antara strategi pemasaran dengan penjualan

Ha : Ada pengaruh secara signifikan antara strategi pemasaran dengan penjualan.

Kriteria Pengujian pada penelitian ini, sebagai berikut :

Ho diterima jika Signifikansi $>0,05$

Ho ditolak jika Signifikansi < 0,05

Berdasarkan hasil pengujian yang tertera pada hasil output SPSS, pada tabel Coefficients diketahui nilai t sebesar 1,350 dengan nilai Signifikansi 0,018, artinya nilai sig. tersebut $<0,05$ maka dapat di simpulkan Ho ditolak dan Ha diterima, artinya Ada pengaruh secara signifikan antara strategi pemasaran dengan penjualan.

b. Uji Determinasi (R2)

Koefisien determinasi (R2) bertujuan untuk mengetahui seberapa besar kemampuan variabel independen menjelaskan variabel dependen. Dalam output SPSS, koefisien determinasi terletak pada tabel Model Summary dan tertulis R Square.

Nilai $\mathrm{R}$ yang merupakan simbol dari nilai koefisien korelasi. Pada hasil olahan data di atas nilai korelasi adalah 0,839 atau $83,9 \%$. Dengan demikian dapat dikatakan bahwa besarnya pengaruh variabel strategi pemasaran terhadap penjualan adalah $83,9 \%$ sedangkan sisanya $(16,1 \%)$ dipengaruhi oleh variabel lain di luar penelitian seperti pada tabel 10 dibawah ini :

Tabel 10

Hasil Uji Coefficients Determinasi (R-Square)

\section{KESIMPULAN}

Dari hasil penelitian, maka kesimpulan yang dapat diambil mengenai pengaruh strategi pemasaran terhadap penjualan pada anyaman bidai kerajinan tangan masyarakat desa Jagoi Babang adalah sebagai berikut :

a. $\mathrm{F}$ hitung sebesar 1.822 dengan signifikansi sebesar 0,018 karena signifikansi < alpha (0.05) maka H0 ditolak: artinya terdapat pengaruh yang signifikan antara strategi pemasaran terhadap penjualan.

b. Variabel strategi pemasaran berpengaruh sangat kuat dan dominan terhadap penjualan dengan angka sebesar 3.466 dengan signifikansi sebesar 0.018 , artinya bahwa ada pengaruh secara signifikan antara strategi pemasaran dengan penjualan. Karena koefisien korelasi nilainya positif, maka berarti strategi pemasaran berpengaruh positif dan signifikan terhadap penjualan. Jadi dalam kasus ini dapat disimpulkan bahwa strategi pemasaran berpengaruh positif terhadap penjualan anyaman bidai kerajinan tangan desa Jagoi 


\section{REFERENSI}

Arikunto, Suharsimi. 2014. Prosedur Penelitian Suatu Pendekatan Praktik. Jakarta: Rineka Cipta.

Louis E. Boone \& David L. Kurtz. 2014. Pengantar Bisnis Kontemporer. Jakarta: Penerbit Salemba Empat Margono.2010. Metodoligi Penelitian Pendidikan. Jakarta : Penerbit Rineka Cipta.

Masri Singarimbun. 2017. Metode Penelitian Survei, Edisi Revisi. Jakarta: Penerbit Pustaka LP3ES.

Sofjan Assauri. 2010. Manajemen Pemasaran. Jakarta: Penerbit Raja Grafindo Persada Divisi Rajawali Pers.

Sugiyono. 2017. Metode Penelitian Kuantitatif, Kualitatif dan $R \& D$. Bandung: Penerbit Alfabeta.

Wiratna Sujarweni. 2014. Metode Penelitian Lengkap, Praktis, dan Mudah Dipahami. Yogyakarta: Pustaka Baru Press 